\title{
PRO DAN KONTRA PENAFSIRAN ZAMAKHSYÂRI TENTANG TEOLOGI MU'TAZILAH DALAM TAFSÎR AL-KASYSYÂF
}

\author{
Bustami Saladin \\ (Calon D osen STA IN Pamekasan, JI. Raya Panglegur Km. 04 Pamekasan, email: \\ bustamisaladin@yahoo.co.id)
}

\begin{abstract}
A bstract:
In general, the interpretation of the Qur'an is based on the Sunnah Rasulullah SAW explanation (tafsîr bi alma'tsûr) and the results of the experts thought of ijtihad (tafsîr bi al-ma'qûl) and both must go hand in hand and complement each other. Interpretation of the holy verses of the Qur'an have been carried out by the mufassirîn from various streams such as Sunni, Shi'a and Mu'tazilite and in many ways we see the various differences of interpretation that they are doing whether in relation to issues of figh, philosophy and related to the verses, and the different interpretations that they have done is something that no longer disputed. All the teachings of Islâm, including about tawhid discussed in the science of kalam is derived from the Qur'an and the hadits, both of the flow Khawarij, Murji'ah, A sy'ariyah, Mu'tazilite, all of which underlie their views with the two-runway, but because there are different interpretations of the Qur'an made by each of these streams then arises the theological understandings that vary as well.
\end{abstract}

\section{Key Words:}

Tafsîr bi al-ma' tsûr, tafsîr bi al-ma' qûl, Mu'tazilah, Zamakhsyari, dan al-Kasysyâf

\section{Pendahuluan}

Al-Qur'ân diyakini oleh kaum Muslim sebagai kitab petunjuk ilahi yang diturunkan kepada nabi Muhammad SAW bagi kepentingan manusia untuk mencapai kebahagiaan dunia dan akhirat, kebahagiaan adalah tujuan utama seluruh manusia. Oleh 
Bustami Saladin

sebab itu, tidaklah mengherankan apabila umat Islâm mencurahkan perhatian yang sangat besar terhadap isi dan kandungan al-Qur'ân.

Kaum Muslim semenjak awal Islâm telah berusaha menggali petunjuk al-Qur'ân untuk diamalkan dalam berbagai aspek kehidupannya, usaha mereka telah meninggalkan warisan kekayaan yang sangat besar yang mendatangkan banyak kebaikan tidak hanya bagi kaum muslimin tetapi juga kepada umat yang lain pada umumnya baik dalam bentuk tatanan sosial maupun literatur ilmu pengetahuan lainnya. Hampir tidak ada satu ilmu pun yang dikenal dalam sejarah Islâm yang tidak didorong oleh pengabdian untuk menggali isi dan kandungan al-Qur'ân, misalnya ilmu nahwu yang bertujuan untuk menjaga bahasa agar menjadi baik dan benar, digali dan diajarkan agar tidak terjadi kekeliruan dalam membaca dan memahami isi dan kandungan al-Qur'ân, ilmu balaghah menguraikan keindahan bahasa Arab yang diabadikan untuk mengungkap keistemewaan dan rahasia-rahasia sastra serta meneliti kata-kata dan ungkapan ungkapan al-Qur'ân, ilmu tajwid dan qira' at yang disusun untuk menetapkan cara membaca dan lahjah yang terdapat dalam alQur'ân, ilmu kalam dikembangkan guna menjelaskan pokok-pokok akidah dalam Islâm dan dalil-dalinya juga diambil dari al-Qur'ân.

Al-Qur'ân merupakan pedoman dasar bagi umat Islâm dalam berbagai aspek kehidupan baik yang menyangkut hubungannya dengan Allâh maupun hubungannya dengan sesama manusia. AlQur'ân juga membicarakan berbagai persoalan kemanusiaan yang menyangkut akidah manusia (ilmu kalam) dan juga menyangkut tentang pembahasan al-Qur'ân itu sendiri (ilmu al-Qur'ân). Untuk dapat memahami al-Qur'ân dengan jelas dan benar maka diperlukanlah tafsir al-Qur'ân atau penjelasan terhadap ayat-ayat alQur'ân

Pada umumnya tafsir al-Qur'ân didasarkan pada penjelasan Rasâlullâh SAW melalui sunnahnya (tafsîr bi al-ma'tsûr) dan hasil ijtihad pemikiran para ahli (tafsîr bi al-ma'qûl) dan keduanya harus berjalan seiring dan saling melengkapi. ${ }^{1}$ Lebih dari itu, penafsiran tentang ayat-ayat suci al-Qur'ân telah banyak dilakukan oleh para

${ }^{1}$ Hasbi A sh-Shiddieqi, Sejarah Pengantar IImu al-Qur'an dan Tafsir (Semarang: PT Pustaka Rizki Putra, 2000), hlm. 227 
mufassir dari berbagai macam aliran, seperti aliran Sunni, Syî'ah dan Mu'tazilah dan di dalam berbagai hal terlihat adanya berbagai perbedaan penafsiran yang mereka lakukan baik yang berkaitan dengan masalah figh, filsafat maupun yang berkaitan dengan ayatayat kalam. Perbedaan penafsiran yang dilakukan mereka adalah suatu hal yang tidak dipertentangkan lagi.2

Seluruh ajaran Islâm termasuk tentang tauhid yang dibahas dalam ilmu kalam adalah bersumber dari al-Qur'ân dan hadits, baik dari aliran Khawârij, Murji'ah, Asy'ariyah, Mu'tazilah, kesemuanya melandasi pandangan mereka dengan dua landasan tersebut. Namun karena terdapat perbedaan penafsiran al-Qur'ân yang dilakukan oleh masing-masing aliran tersebut maka timbullah pemahamanpemahaman teologi yang berbeda-beda pula.

Di tengah-tengah masyarakat masih terdapat adanya anggapan bahwa kaum Mu'tazilah hanya percaya kepada akal dan mengabaikan wahyu. Bahkan di dalam kitabnya I banât, Imam A bû Hasan Asy'âri menyebutkan bahwa aliran Mu'tazilah telah menyimpang dari kebenaran. ${ }^{3}$ Ditambahkan oleh Ali Mushtâfâ alGhurabi bahwa kaum Mutazilah telah memiliki kebebasan berfikir dan berpegang teguh kepada akal dan ia juga mengatakan bahwa kaum Mu'tazilah tidak terikat dengan nash al-Qur'ân. ${ }^{4}$ Kaum Mu'tazilah telah dianggap menyimpang dari wahyu dan hanya mengakui kebenaran yang diperoleh dari akal akhirnya menimbulkan kesan bahwa pemikiran Mu'tazilah berada diluar ajaran Islâm.

Salah satu tafsir yang banyak mendukung pemahaman Mu'tazilah adalah Tafsîr al- K asysyâf ' an H aqâiq G haw âmidl al-T anzîl wa U yûn Aqâwil fî Wujûh al-Ta'wil yang ditulis oleh Abu Qâsim Mahmûd Zamakhsyâri. Tafsîr al-K asysyâf adalah sebuah kitab tafsir yang ditulis oleh Zamakhsyâri yang dikenal sangat mendukung paham Mu'tazilah dalam penafsirannya. Karenanya, sebagian ulama

\footnotetext{
2 Mannã Khalil al-Qaththân, Studi IImu-IImu al-Q ur'an, terj. Muzakkir AS, (Jakarta: PT Pustaka Litera A ntar N usa, 2000), hlm. 455

${ }^{3}$ A bû al-ㅂasan Ali ibn Ismâ'îl al- Asy'ari, al-Ibanât an U shûl al-D iyânât, (Beirut: Dâr al-Kitab al-A rabi,1985), hlm. 6

4 Ali Musthâfâ al-Ghurabi, Târîkh al- Firâq al- Islâmiyah (Kairo:Matba'ât Muhammad Ali Sabih, 1995), hlm. 54
} 
Bustam Saladin

mengkritisi dan menganggap tafsir ini tercela dan sesat, dan sebagian lagi mengagumi kehebatan bahasa dalam tafsir tersebut

\section{Latar Belakang Penulisan Tafsir Al-Kasysyâf}

Zamakhsyâri atau nama lengkapnya $\mathrm{A}$ bu Q âsim M ahmûd ibn U mar al-Zamakhsyâri al-Khawârizmi, lahir di Khawarizmi padā27 Rajab $467 \mathrm{H}$. Ayahnya bernama Umar ibn Muhammad Ibn Umar berasal dari keturunan Khawarizm (Turkistan Asia Tengah ). ${ }^{5}$ Pada masa pemerintahan Sultan Jalâl ad-Dîn Abi Fath Maliksyah dengan wazirnya Nizâm al-Mulk yang dikenal sebagai orang yang sangat aktif dalam mengembangkan kegiatan keilmuan, ia mempunyai kelompok diskusi yang sangat maju dan selalu dihadiri oleh para ilmuan dari berbagai kalangan. ${ }^{6}$

Zamakhsyâri dilahirkan dan dibesarkan di negeri yang sarat dengan ulama dan para cendikiawan. Suasana lingkungan yang sangat dinamis dan pola pemikiran yang berkembang ditempat tersebut didominasi oleh pemahaman Mu'tazilah, sehingga nama Khawarizm pada saat itu identik dengan orang yang berfaham Mu'tazilah.

Menjelang usia remaja beliau pergi meninggalkan desanya untuk menuntut ilmu ke Bukhara, sebuah pusat ilmu pengetahuan yang terkemuka pada saat itu. Baru beberapa tahun ia belajar, ia terpaksa pulang karena ayahnya meninggal dunia. Kemudian Zamakhsyâri bermukim di Khawarizm dan berguru kepada Mahmûd bin Jarâr al-Dâbi al-Isfahani Abû Mudlar an-Nawâwi atau yang dikenal dengan Abû Mudlar, seorang tokoh Mu'tazilah yang mengusai berbagai macam ilmu.7 Di bawah bimbingan A bû Mudlar, Zamakhsyâri berhasil menguasai sastra Arab, logika, filsafat dan teologi dan beliau menjadi salah satu ulama yang disegani dan menempati posisi yang cukup tinggi dalam bidang pemerintahan.

Namun setelah mengalami kekecewaan yang mendalam dalam pemerintahan serta sakit yang dideritanya, Zamakhsyâri

5 Husayn al-Dzahabi, Tafsîr wa al-M ufassirûn, Jilid I (Beirut: Dâr al-Kutub al-Hadîtsah, 1979), hlm. 430

6 Musthâfq al- Shâwi al-Juwayni, M anhâj al- Zamakhsyâri fî T afsîr al-Q ur' an wa bayân

I 'jâzih (Mesir : Dâr al-Maâ'rif, 1968), hlm. 23-24

7 Qaththân, Studi IImu-IImu, hlm. 347 
berkosentrasi pada pengkajian agama, seperti mengajar dan menulis kitab serta mengadakan rihlah ilmiah. Beliau pergi ke Baghdad dan di sana beliau menjumpai beberapa ulama untuk mengikuti pengajianpengajian, di antaranya beliau belajar hadits kepada Abû alKhaththâb, A bû Saâd al-Syaqâni dan A bû Mansûr al- Harisi. Beliau juga belajar fiqh kepada al-Syârif ibn Syajari.

Pada tahun $526 \mathrm{H}$ hingga tahun $529 \mathrm{H}$ Zamakhsyâri berada di Makkah dan berhasil menulis sebuah kitab tafsir al-Kasysyâf. Tafsir alKasysyâf yang beredar sekarang ini terdiri atas empat jilid disertai dengan tambahan tahqîq oleh ulama. Jilid pertama mencakup uraian mengenai muqaddimah yang oleh al-Zamakhsyâri, yang disebut sebagai khutbah al-Kitâb yang berisi beberapa penjelasan penting tentang penyusunan kitab tafsir ini. Jilid ini pula yang memuat tafsir mulai dari surah al-Fâtihah sampai surah al-Nisâ (surah ke-5). Jilid kedua berisi penafsiran yang terdapat pada surah al-An'âm sampai pada surah al-Anbiyâ' (surah ke-21). Jilid ketiga berisi penafsiran ayat-ayat yang terdapat dalam surah al-Hajj sampai dengan ayat-ayat yang terdapat di dalam surah al-Hujurat (surah ke-49). Terakhir, jilid keempat berisi penafsiran ayat-ayat yang terdapat dalam surah Qaf sampai dengan ayat-ayat yang terdapat di dalam surah al-N âs (surah ke-114).

Al-Zamakhsyâri melakukan penafsiran secara lengkap terhadap seluruh ayat Al-Qur'ân, dimulai ayat pertama surah alFâtihah sampai dengan ayat terakhir surah al-Nas. Dari sisi ini dapat dikatakan bahwa penyusunan kitab tafsir ini dilakukan dengan menggunakan metode tahlilî, yaitu suatu metode tafsir yang menyoroti ayat-ayat al-Qur'ân dengan memaparkan segala makna dan aspek yang terkandung di dalamnya sesuai urutan bacaan dalam mushaf Utsmâni. Al-Zamakhsyâri sebenarnya tidak melaksanakan semua kriteria tafsir dengan metode tahlilî, tetapi karena penafsirannya melakukan sebagian langkah-langkah itu, maka tafsir ini dianggap menggunakan metode tafsir tahlilî. Aspek lain yang dapat dilihat, penafsiran al-Kasysyâf juga menggunakan metode dialog, di mana ketika al-Zamakhsyâri ingin menjelaskan makna satu kata, kalimat, atau kandungan satu ayat, ia selalu menggunakan kata in qulta (jika engkau bertanya). Kemudian, ia menjelaskan makna kata atau frase itu dengan ungkapan qultu (saya menjawab). Kata ini selalu 
Bustami Saladin

digunakan seakan-akan ia berhadapan dan berdialog dengan seseorang atau dengan kata lain penafsirannya merupakan jawaban atas pertanyaan yang dikemukakan. Metode ini digunakan karena lahirnya kitab al-Kasysyâf dilatarbelakangi oleh dorongan para murid al-Zamakhsyâri dan ulama-ulama yang saat itu membutuhkan penafsiran ayat dari sudut pandang kebahasaan, sebagaimana diungkapkan sendiri dalam muqaddimah tafsirnya:

"Sesungguhnya aku telah melihat saudara-saudara kita seagama yang telah memadukan ilmu bahasa Arab dan dasar-dasar keagamaan. Setiap kali mereka kembali kepadaku untuk menafsirkan ayat al-Qur'ân, aku mengemukakan kepada mereka sebagian hakikat-hakikat yang ada di balik hijab. M ereka bertambah kagum dan tertarik, serta mereka merindukan seorang penyusun yang mampu menghimpun beberapa aspek dari hakikat-hakikat itu. M ereka datang kepadaku dengan satu usulan agar aku dapat menuliskan buat mereka penyingkap tabir tentang hakikathakikat ayat yang diturunkan, inti-inti yang terkandung di dalam firman A llâh dengan berbagai aspek takwilannya. A ku lalu menulis buat mereka (pada awalnya) uraian yang berkaitan dengan persoalan kata-kata pembuka surat (al-fawâtih) dan sebagian hakikat-hakikat yang terdapat dalam surah al-Baqarah. Pembahasan ini rupanya menjadi pembahasan yang panjang, mengundang banyak pertanyaan dan jawaban, serta menimbulkan persoalan-persoalan yang panjang." 8 .

Di kalangan ulama, al-Zamakhsyâri dikenal dengan orang yang sangat luas ilmunya dan wawasannya dan ahli dalam munadzarah (berdiskusi). Hal ini terlihat dari banyaknya orang-orang yang ingin menuntut ilmu dan berdiskusi kepadanya. Kehebatan al-Zamakhsyâri juga diakui di kalangan ulama generasi berikutnya di samping banyak juga kritikan yang ditujukan kepadanya. Beliau wafat tanggal 9 Zulhijjah 538 H di desa Jurjâniyah. ${ }^{9}$

Zamakhsyâri termasuk ulama yang produktif dalam mengarang karya tulis, ini terlihat dari banyaknya karya tulis beliau, di antaranya adalah A I-M ufrâd wa al-M uallâf fi al-N ahwi, al- N amujâz fi

8 A bû Qâsim Mahmûd ibn Umar al-Zamakhsyâri al-Khawârizm, “Muqaddimah”, dalam al- Kasysyâf 'an $\underline{H}$ aqâiq G hawâmidl al-Tanzîl wa U yûn A qâwil fî Wujûh at-Ta' wîl, (Libanon: Dar al Kutub al-IImiyah, 1995). Lihat juga Software CD M aktabah Syamilah (Kuwait: Global Islamic Software Company, 2002)

${ }_{9}$ Qaththan, Studi IImu-IImu, hlm. 388 
an-N ahwi, al-M ustasqa fî amstâl al-'Arâb, al- M iufassâl fi al-Rahwi, alMinhâj fî U shûl, al-M asâil Fiqhiyah, al- Fâiq fî Tafsîr al-hadîts dan sebagainya. Dari sekian banyak karyanya tafsir al-Kasysyâf adalah karyanya yang paling momumental.

\section{Karekteristik Tafsîr al-Kasysyâf dalam Corak M u'tazilah}

Kitab tafsîr al-Kasysyâf atau lengkapnya al- Kasysyâf 'an $\underline{\mathrm{H}}$ aqâiq Ghawâmidl al-Tanzîl wa U yûn A qâwil fî Wujûh al-Ta'wîl (Menyingkap Tabir Hakikat Wahyu dan Mata Air Hikmah dalam Ragam Penta'wilan) diselesaikan oleh Zamakhsyâri dalam relatif waktu yang sangat singkat, yakni tiga tahun.

Dalam mukaddimah tafsîr al-Kasysyâf, al-Zamakhsyâri mengungkapkan latar belakang penulisan kitab tafsir ini. Ada beberapa faktor yang melatarbelakangi penulisan tafsir ini, di antaranya adalah: (1) Semakin banyaknya permintaan agar beliau menulis sebuah kitab tafsir; (2) antusiasme masyarakat yang begitu besar untuk mengetahui apa-apa yang beliau jelaskan seputar ayatayat al-Qur'ân sehingga kalau kita cermati nama tafsir ini tidak terlepas dari kondisi yang melatarbelakanginya.

Kasysyâf secara etimologi berarti menyingkap atau membuka. Ini berarti bahwa tafsirnya sengaja ditulis dengan maksud untuk membuka dan menyingkap rahasia-rahasia makna dan pengertian alQur'ân yang banyak ditanya oleh umat pada waktu itu. Latar belakang al-Zamakhsyâri sebagai seorang pakar bahasa Arab memiliki pengaruh yang sangat besar dalam penulisan tafsir ini. Dalam penafsirannya Zamakhsyâri menggunakan pendekatan bahasa sehingga tafsîr al-Kasysyâf ini memiliki satu corak penafsiran yang sangat kental dengan corak lughawî (bahasa). Di samping kapasitas keilmuan Zamakhsyâri dalam bidang bahasa dan sastra Arab yang tidak bisa diragukan lagi, faktor lain tafsîr al-K asysyâf disusun dengan corak bahasa adalah minat penduduk $M$ asyrîq dengan kesusastraan A rab lebih besar dibandingkan dengan penduduk M aghrîb. 10

Selain itu, karakteristik lain yang menonjol dalam tafsîr alKasysyâf adalah adanya kecenderungan pendapat pada pemahaman

10 A h hmad al-Shibrashi, Q ishahat al-Tafsir, (Kairo: Dâr al- Qalam, 1962), hlm. 108 
Bustami Saladin

Mu'tazilah. Pengaruh pendapat Mu'tazilah dalam tafsîr al-Kasysyâf telah dikaji oleh para ulama. Di antara ulama yang telah berhasil menjelaskan dan membukukan teologi Mu'tazilah dalam tafsir alKasysyâf adalah al-alammâh A hnmad Al-Nayyir, dalam kitab alIntishâf, al-Hafidz Ibnu Hajar al-Asqâlani, dalam al-Syafi fî Takhrîj A hâdits al-K asysyâf, dan Syaykh Muhammad Ulyân al-M arzuki, dalam Hasyiyah Tafsîr al-Kasysyâf dan M asyâhidah Inshâf 'A lâ Syawâhid alKasysâf

Dalam tafsîr al-Kasysyâf Zamaksyâri selalu mendukung pemahaman Mu'tazilah, sehingga terkesan tafsir al-Kasysyâf merupakan tafsir Mu'tazilah. Di antara ajaran-ajaran dalam teologi Mu'tazilah adalah:

\section{Tawhid}

Tawhid pada hakikatnya merupakan inti ajaran Islâm, Mu'tazilah menempatkan taw hid sebagai prinsip pertama dalam alushûl al-khamsah mereka. Ini berarti kaum Mu'tazilah tidaklah menambahkan yang baru terhadap Islâm. Mereka hanya melakukan suatu upaya pemurnian terhadap pemahaman tawhid agar tidak terseret kepada pemahaman yang merusak makna keesaan Allâh.

Berkenaan dengan pemahaman bahwa manusia bisa melihat Tuhan di Akhirat kelak, aliran Mu'tazilah menolak pemahaman ini, karena menurutnya Tuhan bersifat imateri, sedangkan mata manusia dan manusia itu sendiri bersifat materi. Dalam QS. al-An'am: 103 disebutkan.

$$
\text { لا تُدْرِ كُهُ الأبَْْارُ وَهُوَ يُدْرِكُ الأبْصَارَ وَهُوَ اللَّطِيفُ الْخَبِيرُ }
$$

"Dia tidak dapat dicapai oleh penglihatan mata, sedang dia dapat melihat segala yang kelihatan; dan dialah yang $M$ aha halus lagi $M$ aha M engetahui.".11

Menurut Zamakhsyâri ayat ini sebagai penjelasan bahwa Tuhan tidak dapat dilihat dengan mata kepala kapan pun. Lafad nafi

11 Mujtama' al-Mâlik Fahd li Thibâ'ah al- Mushaf al-Syarîf Madînah Munawwarah, Al-Qur'an dan Terjemahnya, (Saudi Arabia: Mujtama' al-Mâlik Fahd li Thibâ'ah alMushaf al-Syarîf Madînah M unawwarah, 1418), hlm. 196 
(lâ) yang terdapat pada ayat tersebut berlaku umum, tidak terkait waktu dan tempat tertentu, baik di dunia maupun di akhirat. Zamakhsyâri berpendapat bahwa karena Tuhan bersifat imateri, maka Tuhan tidak dapat dilihat dengan mata kepala.12

Dalam menaggapi QS. al-Qiyâmah: 22-23, yaitu:

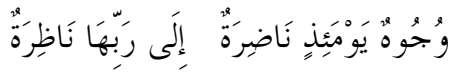

"Wajah-wajah (orang-orang mukmin) pada hari itu berseri-seri. Kepada Tuhannyalah mereka M elihat. ${ }^{13}$

Kata nâzhirah diartikan oleh Zamakhsyâri dengan arti altawaqqu wa al-raja' (penantian dan pengharapan).14

\section{Al-'AdI}

Al-'A dl di sini adalah keadilan Tuhan, yang kaitannya dengan perbuatan-perbuatan Tuhan. Tuhan dikatakan adil jika perbuatanperbuatan Tuhan itu bersifat baik. Tuhan tidak akan berbuat buruk (dzalim) terhadap manusia. Menurut aliran Mu'tazilah, manusia mempunyai kebebasan dalam berkehendak dan berkuasa atas perbuatan-perbuatannya. Seperti yang telah dijelaskan dalam QS. alBaqarah: 272

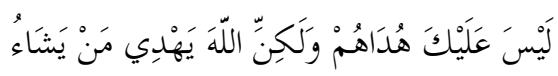

“Bukanlah kewajibanmu menjadikan mereka men dapat petunjuk, akan tetapi Allah-lah yang memberi petunjuk (memberi taufiq) siapa yang dikehendaki-N ya.". ${ }^{15}$

Dalam ayat ini Zamakhsyâri berpendapat bahwa hudâ (petunjuk) bukanlah Allah yang menciptakannya, akan tetapi hamba sendiri yang menciptakannya untuk dirinya sendiri.

12 Abu Qâsim Mahmûd ibnu Umar al-Zamakhsyâri al-Khawârizm, al- Kasysyâf 'an H aqâiq Ghaw âmidl al-Tanzîl wa U yûn A qâwil fî Wujûh at-Ta'wîl, Jilid II (Libanon: Dar al Kutub al-IImiyah, 1995), Lihat juga Software CD M aktabah Syamilah (Kuwait: Global Islamic Software Company, 2002)

13 Mujtama' al-Mâlik, A I-Q ur' an, hlm. 998

${ }^{14}$ al-Zamakhsyâri, T afsir Surat al-Q iyamah ay at 22-23, hlm. 245

15 Mujtama' al-Mâlik, A I-Q ur'an, hlm. 68 
Bustami Saladin

Dalam ayat ini Zamakhsyâri mengartikan hudâ dengan arti kata luthf (kelembutan) dan tawfiq. Zamakhsyâri membelokkan petunjuk (hudâ) Allah kepada makna luthf (kelembutan) dengan sebab bahwa hamba yang menciptakan petunjuk untuk dirinya sendiri, sebagaimana yang terdapat dalam al-Qur'ân surat al-N isa': 79

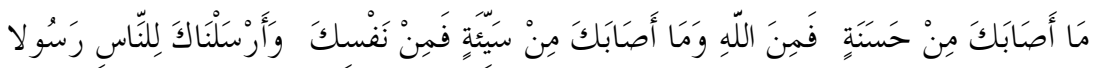

$$
\begin{aligned}
& \text { وَكَفَى باللَهِ شَهيدًا }
\end{aligned}
$$

" A pa saja nikmat yang kamu peroleh adalah dari Allah, dan apa saja bencana yang menimpamu, maka dari (kesalahan) dirimu sendiri Kami mengutusmu menjadi Rasul kepada segenap manusia. Dan cukuplah Allah menjadi saksi".16

Di samping itu keadilan Tuhan juga dibicarakan dalam kaitan dengan perbuatan manusia yang bebas dan merdeka tanpa paksaan. Jika manusia dituntut melakukan perbuatan-perbuatan baik dan menjauhi perbuatan jahat, maka manusia harus mempunyai kebebasan untuk menentukan perbuatannya itu sendiri. Dengan demikian, Allâh tidak akan menjatuhkan pahala atau siksa kepada seorang hamba kecuali berdasarkan pilihan bebas dari hamba itu sendiri. Lanjutan dari jalan pikiran ini adalah bahwa Tuhan tidak memberikan beban yang tidak bisa terpikul oleh manusia. Untuk itu Tuhan memberikan daya kepada manusia agar ia mampu memikul beban tersebut serta memberi ganjaran atas perbuatan manusia sendiri. Dan kalau Tuhan memberikan siksaan kepada manusia, maka siksaan itu adalah untuk kepentingan dan kemaslahatan manusia, maka itu berarti Tuhan telah melalaikan kewajibannya sendiri. Namun bagi Mu'tazilah mengatakan Tuhan bersifat baik dengan perbuatan-perbuatan-Nya, belumlah cukup untuk menyatakan keMahabaikan Tuhan. Untuk itu, haruslah diyakini, Tuhan wajib memberikan yang baik dan terbaik bagi manusia (al-Shalâh wa alAshlah)

Datangnya seorang rasul sangat berguna dan bermanfaat bagi manusia. Menurut Mu'tazilah, mengirimkan Rasul kepada umat

16 Ibid., hlm. 117. 
manusia agar manusia mendapat yang baik dan terbaik, juga merupakan kewajiban bagi Tuhan.

\section{Al-Wa'ad wa al-Wa'id (Janji dan Ancaman)}

Mu'tazilah mengedapankan pula bahwa janji dan ancaman Tuhan pasti terjadi. Allah berjanji dalam kitab suci untuk memasukkan orang yang berpahala ke dalam surga dan orang yang berdosa ke dalam neraka. Oleh sebab itu, menurutnya Tuhan tidak akan melakukan yang sebaliknya, memasukkan orang yang berdosa ke dalam surga dan memasukkan orang yang berpahala ke dalam neraka. Seperti yang tertera dalam QS. Yâsîn: 54

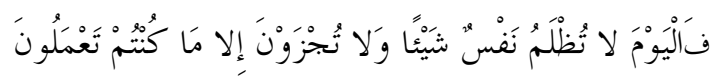

" M aka pada hari itu seseorang tidak akan dirugikan sedikit pun dan kamu tidak dibalasi, kecuali dengan apa yang telah kamu kerjakan" .17

Zamakhsyâri berpendapat bahwa orang kafir akan kekal di dalam neraka. Terkait dengan janji dan ancaman ini adalah Mu'tazilah menolak adanya syafâ' ah (pengampunan pada hari kiamat) dengan mengenyampingkan ayat-ayat yang berbicara tentang syafâ'ah. A rgumen yang dibawanya adalah bahwa syafâ' ah merupakan hal yang berlawanan dengan prinsip al-Wa'ad wa al-Wa'id.

\section{Al-Manzilah bayna al-Manzilatayn}

Al-M anzilah bayna al-M anzilatayn secara harfiah berarti posisi di antara dua posisi. Menurut Mu'tazilah bahwa yang dimaksud ungkapan itu adalah suatu tempat yang terletak di antara surga dan neraka. Washil bin Atha rela memisahkan diri dari Hasan al-Basri sebagai gurunya.Washil berpendirian bahwa orang yang berbuat dosa besar selain syirik, tidak termasuk mukmin dan tidak pula kafir, tetapi fasik, suatu posisi diantara dua posisi yaitu antara mukmin dan kafir. Golongan Khawârij berpendapat bahwa orang tersebut menjadi kafir dan akan kekal di neraka. Golongan Murji'ah berpendapat bahwa orang tersebut tetap mukmin, tidak kekal di negera dan

17 lbid., hlm. 710. 
Bustami Saladin

mengharapkan rahmat dan ampunan dari Allah. Dan golongan Mu'tazilah berpendapat bahwa orang tersebut tidak mukmin dan tidak kafir tetapi fasiq dan akan kekal di neraka, tetapi siksanya lebih ringan dari orang kafir.

Allah SWT telah menjelaskan dalam AI-Qur'an surat al-'An'âm ayat 49 .

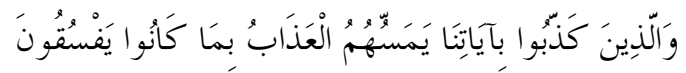

" Dan orang-orang yang mendustakan ayat-ayat Kami, mereka akan ditimpa siksa disebabkan mereka selalu berbuat fasik" 18

\section{Al-Amr bi al-Ma'rûf wa al-Nahy 'an al-Munkar}

Prinsip al-A mr bi al-M a'rûf wa al-N ahy 'an al-M unkar banyak dijumpai dalam al-Qur'ân. Oleh sebab itu prinsip ini bukan hanya milik Mu'tazilah, tetapi juga dianut oleh golongan umat Islâm lainnya. Kaum Mu'tazilah berpendirian bahwa amar ma'ruf nahy munkar merupakan kewajiban yang harus dilaksakan oleh setiap mukmin. Hanya saja dalam pelaksanaan ajaran ini Mu'tazilah mempergunakan kekerasan. Dalam pandangan Mu'tazilah yang dikatakan ma'rûf adalah hal-hal yang mereka anggap benar dan baik menurut ajaran Islâm dan apa-apa yang sejalan dengan pendapat mereka, sedangkan hal-hal yang menyalahinya adalah dipandang munkar yang harus diberantas. Dalam melaksanakan al-A mr bi alM a'rûf wa al-N ahy 'an al-M unkar ini Mu'tazilah berpendapat bahwa bila cukup dilaksanakan dengan seruan dan ajakan yang lunak saja, berarti kewajiban sudah terpenuhi. Tetapi bila seruan dan ajakan yang lunak itu tidak berhasil maka perlu dilaksanakan dengan kekerasan. ayat 17.

Allah SWT telah menjelaskan dalam al-Qur'an surat Luqmân

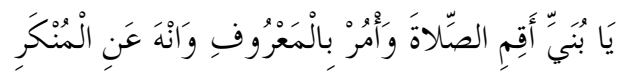

18. Al-Qur'an dan Terjemahnya,Saudi A rabia: M ujtama' al- Malik Fahd li Thiba' ah alM ushaf al- Syarif M adinah M unawwarah, 1418 
" H ai anakku, dirikanlah salat dan suruhlah (manusia) mengerjakan yang baik dan cegahlah (mereka) dari perbuatan yang mungkar" ${ }^{19}$

\section{Pro dan Kontra Penilaian U lamâ' terhadap Tafsir al-Kasysyâf}

Kitab tafsîr al-Kasysyâf ini berjudul lengkap Al-Kasysyâf 'an Haqâiq Ghawâmid al-Tanzîl Wa 'Uyûn al-Aqâwîl Fî Wujûh al-Ta'wîl, disusun oleh al-Zamakhsyâri selama tiga tahun, mulai dari tahun 526 H sampai dengan tahun $529 \mathrm{H}$, di Makkah al-Mukarramah, ketika ia berada sedang melakukan ibadah haji yang kedua kalinya. Hal itu diketahui dari pengakuannya sendiri yang dituangkan pada muqaddimah tafsirnya. Dalam hal ini, ia mengatakan bahwa lama penyusunan kitabnya sama dengan lama masa pemerintahan Abû Bakr al-Shiddîq.

Tafsîr al-Kasysyâf adalah salah satu kitab tafsîr bi al-ra'y yang terkenal, yang dalam pembahasannya menggunakan pendekatan bahasa dan sastra. Dalam tafsir ini dijumpai mufradat dengan merujuk kepada ucapan-ucapan orang A rab terhadap sya'ir-sya'ir atau definisi istilah-istilah yang populer. Kadangkala dalam penafsirannya, Zamakhsyari juga mencantumkan tinjauan gramatika atau nahw.20

Kitab tafsîr ini merupakan salah satu kitab tafsîr yang banyak beredar di dunia Muslim, termasuk di Indonesia. Sebagai salah satu kitab tafsîr yang penafsirannya didasarkan atas pandangan Mu'tazilah, Zamakhsyâri dijadikan corong oleh kalangan Mu'tazilah untuk menyuarakan fatwa-fatwa rasionalnya. Al-Fadhil Ibnu 'A syur berpendapat bahwa tafsîr al-Kasysyâf ditulis antara lain untuk menaikkan pamor Mu'tazilah sebagai kelompok yang menguasai balaghah dan ta'wîl. Namun demikian, kitab ini telah diakui dan beredar luas secara umum di berbagai kalangan, tidak hanya di kalangan non A hl al-Sunnah wa al-Jamâ'ah, tetapi juga di kalangan A hl al-Sunnah wa al-Jamâ'ah.

Kitab tafsîr al-Kasysyâf karya Zamakhsyâri ini diakui oleh para ulama sebagai kitab tafsir yang bernilai tinggi. Ia memiliki beberapa

19. Al-Qur'an dan Terjemahnya,Saudi A rabia: M ujtama' al- Malik Fahd li Thiba' ah alM ushaf al- Syarif M adinah M unawwarah, 1418

2018 A bû Hasan al-Asy'âri, M aqâlat al-Islamiyyîn wa Ikhtilâf al-M ushallîn, (Mesir: Maktabah al-Nahdhah, 1970), hlm. 126 
Bustami Saladin

keistemewaan dibandingkan dengan kitan-kitab tafsîr lainnya. Keistemewaan tersebut terletak pada pembahasan atau penafsirannya yang mengungkap rahasia-rahasia balaghah yang terdapat dalam alQur'ân.21 Ibnu Khaldun ketika berbicara tentang tafsir yang menggunakan pendekatan kaidah bahasa i'rab dan balaghah mengatakan bahwa di antara sekian banyak tafsir yang memuat berbagai macam keilmuan semacam ini al-Kasysyâf-lah yang paling terbaik.22

Pujian senada juga diucapkan oleh Haydar al-Harawî yang menyebutkan bahwa kitab tafsîr al-Kasysyâf adalah kitab tafsir yang bernilai tinggi belum ada kitab lain yang bisa menandinginya.23 la juga mengakui keistimewaan al-Kasysyâf dari segi pendekatan sastra (balaghah)-nya dibandingkan dengan sejumlah karya tafsir ulama mutaqaddimin lainnya. Menurut Muhammad Zuhayli, kitab tafsir ini yang pertama mengungkap rahasia balaghah al-Qur'ân, aspek-aspek kemukjizatannya, dan kedalaman makna lafal-lafalnya, di mana dalam hal inilah orang-orang Arab tidak mampu untuk menentang dan mendatangkan bentuk yang sama dengan al-Qur'ân. ${ }^{24}$ Lebih jauh, Ibnu 'Asyur menegaskan bahwa mayoritas pembahasan ulama Sunni mengenai tafsir al-Qur'ân didasarkan pada tafsir al- Zamakhsyâri. AlAlûsi, A bû al-Su'ûd, al-Nasafi, dan para mufassir lain merujuk kepada tafsirnya.

Di samping itu, ada juga beberapa kitab yang menyoroti aspek-aspek kitab tafsîr ini, di antaranya al-Kâfi al-Syafi fî Takhrîj A hâdits al-Kasysyâf (Uraian Lengkap Mengenai Takhrîj Hadîts pada Tafsir al-Kasysyâf) oleh Ibnu Hajar al-'Asqâlani, al-Inshâf fî mâ Taqaddamahu al-Kasysyâf min I'tizâl (Menyingkap PandanganPandangan M u'tazilah dalam Tafsir A I-K asysyâf) oleh Imâm Nâshir alDîn A hmad bin Muhammad dan Ibn Munîr al-Iskandari, dan Syarh Syaw âhid al-Kasysyâf (Penjelasan M engenai Syair-Syair dalam Tafsir alKasysyâf) oleh Muhbib al-Dîn Affandi.

\footnotetext{
21 al-Dzahabi, Tafsîr wa M ufassirûn, hlm. 433

$22 \mathrm{lbid} ., \mathrm{hlm} .440$

$23 \mathrm{lbid} ., \mathrm{hlm} .436$

${ }^{24}$ A bd Hay al-Farmawî, A I-Bidâyah fî al-Tafsîr wa al-M awdu'iyyah D irâsat M anhajiyah $M$ awduwiyyah, tt.: tp., t.th., hlm. 41
} 
Penyusunan kitab tafsîr al-Kasysyâf tidak dapat dilepaskan kitab-kitab tafsir yang pernah disusun oleh para mufassir sebelumnya, baik dalam bidang tafsir, hadits, qira'at, maupun bahasa dan sastra. Pada sisi lain, karya al-Zamakhsyâri ini banyak dijadikan sebagai obyek kajian para ulama, baik ulama mutaakhkhirîn maupun para ulama mutaqaddimîn, yang ditujukan terhadap berbagai aspeknya. Dari berbagai kajian tersebut diketahui bahwa di antara para ulama ada yang memberikan penilaian negatif, di samping juga ada yang menilai positif. Komentar-komentar tersebut dapat dilihat antara lain di dalam kitab-kitab yang secara lengkap membahas mengenai hal itu, antara lain, adalah M anhaj al-Zamakhsyâri fî Tafsîr al-Qur'ân wa Bayân I'jâzi karya Musthâfâ Juwayni, al-Tafsîr wa al-M ufassirûn karya al-Dzahabi, M anâhil al-' Irfân fî 'U lûm al-Q ur'ân karya Muhammad Abd al-Adzîm al-Zarqani, Balaghah al-Qur'âniyyah fî Tafsîr al-Zamakhsyâri wa A tsaruhu fî D irâsat al-Balaghiyyah karya Munammad A bû M ûsâ.

Dari kajian yang dilakukan oleh Musthâfâ Juwayni terhadap kitab tafsîr A I-Kasysyâf tergambar delapan aspek pokok yang dapat ditarik dari kitab tafsir itu, yaitu: (1) al-Zamakhsyâri telah menampilkan dirinya sebagai seorang pemikir Mu'tazilah; (2) penampilan dirinya sebagai penafsir atsari, yang berdasarkan atas hadîts Nabi; (3) penampilan dirinya sebagai ahli bahasa; (4) penampilan dirinya sebagai ahli nahw; (5) penampilan dirinya sebagai ahli qira'at; (6) penampilan dirinya sebagai seorang ahli figh; (7) penampilan dirinya sebagai seorang sastrawan; dan (8) penampilan dirinya sebagai seorang pendidik spiritual.

Dari kedelapan aspek itu, menurut al-Juwayni, aspek penampilannya sebagai seorang Mu'tazilah dianggap paling dominan. Apa yang diungkapkan oleh al-Juwayni di atas menggambarkan bahwa uraian-uraian yang dilakukan oleh alZamakhsyâri dalam kitab tafsirnya banyak mengambarkan berbagai pandangan yang mendukung dan mengarah pada pandanganpandangan Mu'tazilah.

Begitu juga halnya dengan al-Zarqani yang menguatkan asumsi itu. Namun demikian, ia juga mencatat beberapa keistimewaan yang dimiliki tafsîr al-Kasysyâf, antara lain: (1) terhindar dari cerita-cerita israiliyyat; (2) terhindar dari uraian yang panjang; (3) 
Bustami Saladin

dalam menerangkan pengertian kata berdasarkan atas penggunaan bahasa A rab dan gaya bahasa yang mereka gunakan; (4) memberikan penekanan pada aspek-aspek bal aghiyyah, baik yang berkaitan dengan gaya bahasa ma'âniyyah maupun bayâniyyah; dan (5) dalam melakukan penafsiran ia menempuh metode dialog.

Para ulama melihat keistemwaan dari tafsîr al-Kasysyâf ini di antaranya karena isinya sederhana dan tidak berbelit-belit, bersih dari kisah-kisah Israiliyat, selalu berpegang teguh pada kaidah kebahasaan dalam menerangkan ayat-ayat dalam al-Qur'ân, uslu b tafsirnya sangat memperhatikan ilmu bayân dan ilmu ma'âni untuk menunjukkan alQur'ân adalah firman Allâh yang tidak akan bisa ditandingi oleh manusia, dalam menjelaskan suatu masalah tafsir ini juga sering menggunakan metode dialog seperti kalimat, "jika anda berkata begitu maka saya akan berkata begini" .25

Kehebatan kemashuran kitab ini terlihat dari banyaknya respon dari para mufassir hal ini terlihat beberapa kitab-kitab syarah dan khulâshah yang menerangkan tentang tafsir ini, di antaranya adalah al- Kasysyâf an M usykilât al-Kasysyâf karya Abû $\underline{\text { Hafs }} \mathrm{Amr}$ ibn Abd al-Rahnman al-Farisi, Syarah al-Kasysysâf oleh Muhnammad bin Muhammad al-Tahtanî al-Râzî, Talkhis al-Kasysyâf oleh Umar bin Dawûd bin Sulayman al-Farisi, al-Tafsîr wa Rijâluhu karya al-Fadhil ibnu 'A syur, M uqaddimah Ibnu Khaldun karya Abd al-Rahmân ibnu Khaldun, M abâhits fî 'Ulûm al-Qur'ân karya Manna' al-Qaththân, alM ufassirûn H ayâtuhum wa M anhajuhum karya Sayyid Muhammad Ali Iyazi; al-Tafsîr wa al-Mufassirûn karya Muhammad Husayn alDzahaby; al-Isra'iliyat wa al-M audhû'at fî Kutub al-Tafsîr karya Muhammad bin Muhammad A bû Shabah, dan sebagainya.

Meskipun banyaknya pujian yang dilontarkan oleh para ulama namun tidak sedikit pula yang mengkritik tafsîr al-Kasysyâf, terutama dari kalangan Ahl al-Sunnah, di antaranya adalah sebagaimana tercantum dalam al- I banât an U shûl al- D iyânâat karya Abû al-ㅂasan Ali ibn Ismâ'îl al- Asy'âri, Târikh al-Firâq al-Islâmiyah karya Ali Musthâfa al-Ghurabi, intishâf min Tafsîr al-Kasysyâf karya A hnmad bin Muhammad bin Manshûr bin Munîr al-Mâliki. Al-

25 Husayn al-Dzahabi, M anâhilul Irfân fî U ûm al-Qur'ân, (Beirut: Dâr al-Kutûb al Hadîtsah, 1979), hlm. 70 
Dzahabî di samping memberikan pujian terhadap kitab tafsir ini juga memberikan kritik dengan menyebutkan sejumlah penyimpanganpenyimpangan yang terdapat dalam tafsîr al-K asysyâf. 26

\section{Penutup}

AI-Qur'ân merupakan pedoman dasar bagi umat Islâm dalam berbagai aspek kehidupan baik yang menyangkut hubungannya dengan Allah maupun hubungannya dengan sesama manusia. AlQur'ân juga membicarakan berbagai persoalan kemanusiaan yang menyangkut akidah manusia (ilmu kalam) dan juga menyangkut tentang pembahasan al-Qur'ân itu sendiri (ilmu al-Qur'ân). Untuk dapat memahami al-Qur'ân dengan jelas dan benar, maka diperlukanlah tafsir al-Qur'ân atau penjelasan terhadap ayat-ayat alQur'ân. Salah satu kitab tafsir yang cukup terkenal adalah al-Kasysyâf atau lengkapnya al- Kasysyâf 'an $\underline{\mathrm{H}}$ aqâiq Ghawâmidl al-Tanzîl wa U yûn A qâwil fî Wujûh al-Ta' wîl, karya Zamakhsyâri.

Kitab tafsîr ini banyak mendukung pemahaman Mu'tazilah, sebuah aliran teologi yang dianggap menyimpang dari wahyu dan hanya mengakui kebenaran yang diperoleh dari akal sehingga menimbulkan kesan bahwa pemikiran Mu'tazilah berada diluar ajaran Islâm. Karenanya, sebagian ulama mengkritisi dan menganggap tafsir ini tercela dan sesat, dan sebagian lagi mengagumi kehebatan bahasa dalam tafsir tersebut

\section{D aftar Pustaka}

Ash-Shiddieqi, Hasbi. Sejarah Pengantar Ilmu al-Quran dan Tafsir. Semarang : PT Pustaka Rizki Putra, 2000.

Asy'âri, Abû al-ㅂasan Ali ibn Ismâ'îl al-. Maqalat al-Islâmiyyîn wa I khtilâf al-M ushallîn. Mesir: Maktabah al-N ahdhah, 1970.

al Ibanât an Ushûl al- Diyânâat. Beirut: Dâr al-Kitâb alArabi,1985

26 al-Dzahabi , T afsîr, hlm. 291 
Bustami Saladin

Dzahabi, Husyain al-. Tafsîr wa al-M ufassirûn. Beirut: Dâr al-Kutub alHadîtsah, 1979).

Farmawî, A bd Hay al-. al-Bidâyah fî al-Tafsîr wa al-M awdû'iyyah D irâsat $M$ anhajiyah $M$ awduwiyyah. T.t: tp., t.th.

Ghurabi, Ali Musthâfâ al-. Târîkh al- Firâq al- Islâmiyah. Kairo: Matba'ât Muhammad Ali Sabih, 1995.

Husayn al-Dzahabi, M anâhil al-Irfan fî U ûm al-Qur'ân. Beirut: Dâr al Kutub al-Hadîtsah, 1979.

Juwaynî, Musthâfa al-Shâwi al-. M anhâj al-Zamakhsyâri fî Tafsîr alQur'ân wa bayân I 'jâzih. Mesir: Dâr al-Maâ'rif, 1968.

Khawârizm, Abu Qâsim Mahnûd ibn Umar al-Zamakhsyâri al-. alKasysyâf ' an $\underline{H}$ aqâiq G hawâmidl al-Tanzîl wa U yûn Aqâwil fi Wujûh al-Ta' wîl, Libanon: Dâr al-Kutub al-IImiyah, 1995.

Qaththân, Mannã Khalil al-. Studi IImu-IImu al-Qur'an. Terj. Muzakkir AS. Jakarta: PT Pustaka Litera A ntar Nusa, 2000.

Mujtama' al-Mâlik Fahd li Thibâ'ah al-Mushaf al-Syarîf Madînah Munawwarah. Al-Qur'ân dan Terjemahnya. Saudi Arabia: Mujtama' al-Mâlik Fahd li Thibâ'ah al-Mushaf al-Syarîf Madînah Munawwarah, 1418.

Shibrashi, A hnmad al-. Q ishahat al-Tafsîr. Kairo: Dâr al-Qalam, 1962

Software CD, M aktabah Syamilah. Kuwait: Global Islamic Software Company, 2000 